\title{
Taking Dialogue Theory Much too Seriously (or Perhaps Charter Dialogue Isn't Such a Good Thing after all)
}

Andrew Petter

Follow this and additional works at: http://digitalcommons.osgoode.yorku.ca/ohlj

Part of the Constitutional Law Commons

Commentary

\section{Citation Information}

Petter, Andrew. "Taking Dialogue Theory Much too Seriously (or Perhaps Charter Dialogue Isn't Such a Good Thing after all)." Osgoode Hall Law Journal 45.1 (2007) : 147-167.

http://digitalcommons.osgoode.yorku.ca/ohlj/vol45/iss1/7 


\title{
Taking Dialogue Theory Much too Seriously (or Perhaps Charter Dialogue Isn't Such a Good Thing after all)
}

\begin{abstract}
This article challenges the thesis of Peter W. Hogg, Allison A. Bushell Thornton, and Wade K. Wright (put forth earlier in this issue) that the frequency of legislative responses to Charter decisions striking down laws, which they refer to as "Charter dialogue," provides evidence that Canada has a weaker form of. judicial review than is thought to exist in the United States. This article also critiques their claim that judicial review is justified by the idea that individuals have rights that cannot be taken away by an appeal to the general welfare'. The author maintains that this claim not only contradicts their previous arguments, but also undermines their position that Charter dialogue, insofar as it allows legislatures to reassert majoritarian objectives following adverse court decisions, is a good thing.
\end{abstract}

Keywords

Canada; Canada. Canadian Charter of Rights and Freedoms; Judicial review 


\section{Commentary}

\section{TAKING DIALOGUE THEORY MUCH TOO SERIOUSLY (OR PERHAPS CHARTER DIALOGUE ISN'T SUCH A GOOD THING AFTER ALL) ${ }^{\odot}$}

\begin{abstract}
This article challenges the thesis of Peter W. Hogg, Allison A. Bushell Thornton, and Wade K. Wright (put forth earlier in this issue) that the frequency of legislative responses to Charter decisions striking down laws, which they refer to as "Charter dialogue," provides evidence that Canada has a weaker form of. judicial review than is thought to exist in the United States. This article also critiques their claim that judicial review is justified by the idea that individuals have rights that cannot be taken away by an appeal to the general welfare. The author maintains that this claim not only contradicts their previous arguments, but also undermines their position that Charter dialogue, insofar as it allows legislatures to reassert majoritarian objectives following adverse court decisions, is a good thing.
\end{abstract}

ANDREW PETTER*
Cet article interpelle la thèse de Peter W. Hogg, Allison A. Bushell Thornton et Wade K. Wright (évoquée plus haut dans ce numéro), selon laquelle la fréquence des réponses législatives aux décisions relatives à la Charte qui abrogent certaines lois, décisions auxquetles ils font allusion sous l'expression "Dialogue de la Charte», démontre que le Canada dispose d'une forme de révision judiciaire plus faible que celle qu'on attribue aux États-Unis. L'article critique aussi leur prétention selon laquelle la révision judiciaire se justifie par l'idée voulant que les particuliers disposent de droits que ne peut pas aliéner un appel à l'intérêt général. L'auteur maintient que cette prétention ne fait pas que contredire leurs arguments précédents, mais ébranle aussi leur position selon laquelle le dialogue de la Charte est souhaitable - tant qu'il permet aux législatures de réaffirmer des objectifs majoritaires suivant des arrêts adverses des tribunaux.

I. INTRODUCTION ...

II. A WEAKER FORM OF JUDICIAL REVIEW (OR NOT)

A. The Importance of Qualitative Analysis ................................................. 152

B. Lessons on Dialogue from the United States.........................................157

C. The Significance of the Insignificance of Section 33...............................161

2007, Andrew Petter.

*Dean and Professor, Faculty of Law, University of Victoria. The author is indebted to Joel Bakan, Benjamin Berger, Gillian Calder, Allan Hutchinson, Hester Lessard, Maureen Maloney, Allyson McKay, and Murray Rankin for their helpful comments and suggestions, and to Lorne Neudorf for his invaluable research assistance. 


\section{INTRODUCTION}

In their original article on Charter dialogue, Peter Hogg and Allison Bushell maintained that certain structural features of the Canadian Charter of Rights and Freedoms ${ }^{1}$ give legislatures the capacity to respond to court decisions that invalidate laws by enacting modified laws accomplishing the same legislative objectives. ${ }^{2}$ According to the authors, this capacity "greatly diminished" any concern about the legitimacy of judicial review because it showed that Charter decisions are not a major obstacle to democratic decision making. ${ }^{3}$ They argued that this diminished concern was justified despite the high degree of discretion exercised by çourts in interpreting the Charter, which they acknowledged "inevitably remakes the constitution into the likeness favoured by the judges."

My initial response to this thesis was mixed. ${ }^{5}$ On the one hand, I applauded the authors' acknowledgement of the subjective nature of Charter decision making and, in light of this, their willingness to reject traditional defences of judicial review based upon the rule of law. I also welcomed their use of democracy as the yardstick of constitutional legitimacy, their acceptance of legislative engagement on rights issues, and their support for legislative supremacy in relation to matters of social and economic policy. Finally, I saw some benefit in the potential of the thesis to encourage judges to lessen their attachment to liberal

\footnotetext{
1 Canadian Charter of Rights and Freedoms, Part I of the Constitution Act, 1982, being Schedule B to the Canada Act 1982 (U.K.), 1982, c. 11.

2 Peter W. Hogg \& Allison A. Bushell, "The Charter Dialogue Between Courts and Legislatures (Or Perhaps The Charter of Rights Isn't Such A Bad Thing After All)" (1997) 35 Osgoode Hall L.J. 75 ["Charter Dialogue"].

${ }^{3}$ Ibid. at 80 .

${ }^{4}$ Ibid. at 77.

5 Andrew Petter, "Twenty Years of Charter Justification: From Liberal Legalism to Dubious Dialogue" (2003) 52 U.N.B.L.J. 187 [Petter, “Charter Justification"]; Andrew Petter, "Rip Van Winkle in Charterland” (2005) 63 Advocate (B.C.) 337.
} 
legalism, and to edge away from the regressive assumptions that animated Charter jurisprudence in the 1980s.

Other aspects of the thesis, however, I found problematic. First, I observed that the thesis was devoid of normative content and exerted no moral claim to support or guide the involvement of judges in Charter decision making. It applied to any and all Charter interpretations, offering reassurance on the basis that, no matter what judges decided, legislatures could find ways to reassert their policy objectives. For this reason, I argued that the thesis at best mitigated, rather than legitimated, the courts' role under the Charter. Second, I maintained that the thesis seriously underestimated the extent to which judicial decision making under the Charter influences public policy in Canada. This it did by: discounting the privileged position that courts occupy in Charter dialogues; treating all legislative responses to court decisions alike, without regard to the extent to which those responses maintained the legislatures' policy objectives; and ignoring the extent to which judicial interpretations of Charter rights permeate public discourse, drive policy decisions, and influence every aspect of political life. Finally, I saw disturbing implications for democracy in the fact that Canadian constitutional scholars had no difficulty advancing a thesis that both acknowledged the political nature of judicial review and defended its legitimacy.

I was not alone in pointing out problems and deficiencies in the arguments concerning Charter dialogue presented by Hogg and Bushell. ${ }^{6}$ Not surprisingly, however, these shortcomings did not discourage the courts and some Charter enthusiasts from embracing a thesis that purported to legitimize the role of judges while placing no

${ }^{6}$ See e.g. F.L. Morton, "Dialogue or Monologue?" (April 1999) 20 Policy Options 23; Christopher P. Manfredi \& James B. Kelly, "Six Degrees of Dialogue: A Response to Hogg and Bushell” (1999) 37 Osgoode Hall L.J. 513; Christopher P. Manfredi \& James B. Kelly, "Dialogue, Deference and Restraint: Judicial Independence and Trial Procedures" (2001) 64 Sask. L. Rev. 323; Jeremy Webber, "Institutional Dialogue between Courts and Legislatures in the Definition of Fundamental Rights: Lessons from Canada (and elsewhere)" in Wojciech Sadurski, ed., Constitutional Justice, East and West: Democratic Legitimacy and Constitutional Courts in PostCommunist Europe in a Comparative Perspective (The Hague: Kluwer Law International, 2002) 61 [Webber, "Institutional Dialogue"]; Keith Ewing, "Human Rights" in Peter Cane \& Mark Tushnet, eds., The Oxford Handbook of Legal Studies (Oxford: Oxford University Press, 2003) 309; Mark Tushnet, "Judicial Activism or Restraint in a Section 33 World" (2003) 53 U.T.L.J. 89; Rainer Knopff, "How Democratic is the Charter? And Does It Matter?" (2003) 19 Sup. Ct. L. Rev. (2d) 199; and Allan C. Hutchinson, "Judges and Politics: An Essay from Canada" (2004) 24 L.S. 275. 
constraints on their decision-making authority. ${ }^{7}$ Therefore, what might properly have been regarded as a modest case for moderating concerns about the undemocratic effects of Charter decisions has been invoked by judges and scholars over the past decade as though it represented a full-fledged theory of judicial review. Moreover, while the thesis advanced by Hogg and Bushell in 1997 implicitly spoke to the desirability of judges showing deference to the policy-making role of legislatures, the thesis has since been harnessed by some courts and commentators to justify more, not less, judicial activism. ${ }^{8}$

The return in this issue of Hogg, Bushell, and a new co-author, to the debate on Charter dialogue provided them an opportunity to reinforce the limitations of their original thesis, to correct some of its deficiencies, and to repudiate its misapplication by courts and scholars. ${ }^{9}$ Unfortunately, they have for the most part gone in the opposite direction, abandoning some of the limitations of their original thesis, adding to its deficiencies, and encouraging its judicial and academic misuse. In short, like so many others, they have fallen prey to the temptation to take dialogue theory much too seriously.

In this response, I do not propose to repeat all of the criticisms that I have advanced previously. Instead I intend to focus on two propositions that are central to the revised thesis presented by the authors in this issue:

1. That the structural features of the Charter, particularly the reasonable limits clause found in section 1 , result in a weaker form of judicial review that provides legislatures with a broader scope to pursue their policy objectives than would otherwise be the case; and

${ }^{7}$ The Supreme Court of Canada embraced the dialogue thesis in Vriend v. Alberta, [1998] 1 S.C.R. 493 [Vriend]. For examples of academic support for the thesis, see Patrick J. Monahan, "The Supreme Court of Canada in the 21st Century" (2001) 80 Can. Bar Rev. 374; Kent Roach, The Supreme Court on Trial: Judicial Activism or Democratic Dialogue (Toronto: Irwin Law, 2001).

${ }^{8}$ See e.g. Vriend, ibid:; Roach, ibid. For discussion of how dialogue theory can encourage courts to become more activist, see Andrew Petter, "Wealthcare: The Politics of the Charter Revisited" in Colleen M. Flood, Kent Roach \& Lorne Sossin, eds., Access to Care, Access to Justice: The Legal Debate Over Private Health Insurance in Canada (Toronto: University of Toronto Press, 2005) 116 at 128-31.

9 Peter W. Hogg, Allison A. Bushell Thornton \& Wade K. Wright, "Charter Dialogue Revisited-Or 'Much Ado About Metaphors"' (2007) 45 Osgoode Hall L.J. 1 ["Charter Dialogue Revisited"]. 
2. That the capacity of legislatures to respond to court decisions under the Charter, while not justifying judicial review, significantly diminishes concerns about the legitimacy of judicial review.

I contend that neither of these propositions is sustainable.

\section{A WEAKER FORM OF JUDICIAL REVIEW (OR NOT)}

The thesis presented by Hogg and Bushell in 1997 was predicated on the claim that Canada has a weaker form of judicial review than is thought to exist in the United States, where "the antimajoritarian objection to judicial review could not be ignored." 10 The reason for this, according to the authors, is that the Charter contains features that enable legislatures to respond to court decisions invalidating legislation, and thereby continue to pursue their policy objectives, albeit in different ways. The authors identified four such features, the most significant of which is the reasonable limits clause in section 1 . They supported this claim by identifying sixty-six Charter cases in which a law had been held to be invalid by the Supreme Court of Canada or lower courts, and by showing that 80 per cent of these cases had triggered some legislative response. ${ }^{11}$ They held these data out as evidence of dialogue and support for their claim that the Charter established a weaker form of judicial review.

In their most recent article, "Charter Dialogue Revisited," Hogg and his co-authors, Allison A. Bushell Thornton and Wade K. Wright ("the authors"), reassert this claim in succinct and definitive terms:

In 1997, the literature on judicial review was predominantly American, and the Canadian contributions naturally drew inspiration from the American literature. Most Canadian writers assumed a "strong form" of judicial review, under which courts usually have the last word. Our study made clear that in Canada we had a weaker form of judicial review that rarely had the effect of actually defeating the purpose of the legislative body. ${ }^{12}$

They also update their data to show that, of the twenty-three Supreme Court of Canada cases since their 1997 article in which a law was held to

\footnotetext{
${ }^{10}$ Supra note 2 at 77

"Ibid. at 97.

12 Supra note 9 at 4.
} 
be invalid under the Charter, 61 per cent elicited some legislative response. ${ }^{13}$

How persuasive is the claim of the authors that this level of legislative response is evidence that section 1 and other Charter features have produced a weaker form of judicial review in Canada? The answer, unfortunately, is that it is not at all persuasive. There are various reasons for this, but chief amongst them are: (i) their focus on quantitative rather than qualitative analysis of Charter decisions and legislative responses; (ii) their inattention to the extent and nature of constitutional dialogues in the United States; and (iii) their failure to consider the significance of legislatures' lack of use of the override clause in section 33 .

\section{A. The Importance of Qualitative Analysis}

Let us turn first to the authors' focus on quantitative rather than qualitative analysis of Charter decisions and legislative responses. According to the authors, any legislative response to a Charter decision invalidating a law is evidence of dialogue. Thus, their count of legislative responses over the two periods they surveyed includes eight cases in which the legislature simply repealed the laws found to be unconstitutional by the courts, and several others in which the legislature "merely implemented the changes the reviewing court had suggested." 14 These cases were included, they said, because it would cast the notion of dialogue "too narrowly to discount those remedial measures that have merely followed the directions of the court, either by repealing or amending an unconstitutional law." ${ }^{15}$ Whether or not one finds this explanation convincing, what it reveals is that the presence of Charter dialogue, as defined by the authors, is no indication of the strength of judicial review. Such strength can be measured only by attending to the nature as well as the number of legislative responses.

To demonstrate this point, consider a situation in which every Charter decision declaring a law to be invalid resulted only in a subsequent repeal of that law or other amendment required by the court. Under Hogg and Bushell's definition of dialogue, this situation

\footnotetext{
${ }^{13} \mathrm{Ibid}$. at 51 .

${ }^{14}$ Supra note 2 at 98.

${ }^{15}$ Ibid.
} 
would constitute a 100 per cent rate of dialogue. Yet by no stretch of the imagination could it be said that this situation provided evidence of a weak form of judicial review. On the contrary, the fact that legislatures in this example gave effect to the judgments of the court in each and every case would suggest an incredibly strong and effective form of judicial review.

There is, in other words, nothing remarkable or revealing about the fact that legislatures respond to judicial decisions that strike down laws. Indeed, given that legislative responses are often required to give effect to such decisions, and to accommodate their impacts upon other aspects of legislative schemes, it would be more remarkable if legislatures did not respond. In assessing the strength of judicial review, therefore, it is necessary to consider the degree to which Charter rulings that strike down laws enable legislatures to achieve their original policy objectives. The only way this can be assessed is through a comprehensive qualitative analysis of the cases-one that evaluates the substance of the court rulings, their impact upon the legislatures' policy objectives, and the extent to which legislative responses were successful in overcoming, as opposed to accommodating, these impacts. Qualitative analysis is also required to identify the secondary impacts of judicial decisions upon legislative policy, as well as the extent to which Charter decisions may affect other government policies and future policy making.

The value of qualitative analysis is illustrated by examining the Supreme Court of Canada's decision in Schachter v. Canada. ${ }^{16}$ The Court in that case confirmed a ruling of the federal court that it was a contravention of the guarantee of equality rights in section 15(1) of the Charter to deny biological parents access to benefits that were available to adoptive parents under the Unemployment Insurance Act. ${ }^{17}$. This left Parliament with the choice of either increasing benefits for biological parents or decreasing them for adoptive parents. Parliament's response, tabled in 1989 as part of Bill C-21 following the federal court's decision and enacted in 1990, was to do both, making such benefits available to all parents for ten weeks, rather than for the fifteen weeks that adoptive

${ }^{16}[1992] 2$ S.C.R. 679 [Schachter].

17 Unemployment Insurance Act, 1971, S.C. 1970-71-72, c. 48 , s. 30, as am. by S.C. $1980-81-82-83$, c. 150 , s. $4,32(1)$, as am. by S.C. $1980-81-82-83$, c. 150 , s. 5 . 
parents had previously enjoyed. ${ }^{18}$ Hogg and Bushell chalk this up as another example of Charter dialogue, noting that "[s]ection 15(1) leaves room for different legislative choices of this kind, such that democratically elected bodies are still ultimately responsible for setting their own budgetary priorities, albeit in a way that does not discriminate against disadvantaged groups." ${ }^{.19}$ This rosy assessment discounts the extent to which Parliament's response to Schachter required it to deviate from its original policy objectives, both by reducing the duration of benefits made available to adoptive parents, and by giving biological parents access to benefits that it had not previously provided them. ${ }^{20}$ Not only did this response represent a major alteration in the statutory scheme, it also required a substantial expenditure of funds that had not previously been authorized by Parliament. ${ }^{21}$

18 An Act to amend the Unemployment Insurance Act and the Employment and Immigration Department and Commission Act, S.C. 1990, c. 40, s. 24.

${ }^{19}$ Supra note 2 at 91.

${ }^{20}$ The frustration felt by Members of Parliament concerning the choice they were forced to make between decreasing benefits for adoptive parents and increasing benefits for biological parents was evident during committee hearings on Bill C-21. Here, for example, is what Barbara McDougall, the Employment and Immigration Minister at that time, said during those hearings when responding to pleas from a government MP that some way be found to restore the benefit for adoptive parents to fifteen weeks:

I am very sensitive to the situation of adoptive parents. We gave considerable thought to this problem when the Bill was being drafted. The problem still exist. [sic] In fact, there are two problems. There is the problem of the Charter of Rights and Freedoms, and that regarding the situation of natural parents and adoptive parents. In addition, the system is open and much more costly. We are trying to find a solution.

Before my appearance here today, I had not found a solution. I am sorry, but that is simply the case....

House of Commons, Minutes of Proceedings and Evidence of the Legislative Committee on Bill C21, 34th Parl., No. 19 (3 October 1989) at 19:31 [English translation] [Minutes].

${ }^{21}$ It is worth noting that a principal reason given by the Supreme Court of Canada for deciding to remedy the Charter violation by striking down the benefit provided to adoptive parents, rather than extending it to biological parents, was that the costs of such an extension would constitute an intrusion into the legislative domain "substantial enough to change potentially the nature of the scheme as a whole." Schachter, supra note 16 at 723 . To the same effect, Hogg, in his constitutional textbook, says that the "remedy of extension directly alters the statutory scheme and requires new expenditures by the federal government that have never been authorized by Parliament," noting that "a court faced with an under-inclusive statute has an unpalatable choice between the draconian remedy of nullification and the radical remedy of extension." Peter W. Hogg, Constitutional Law of Canada, student ed. (Toronto: Thomson Carswell, 2006) at 900 [Hogg, Constitutional Law, 2006]. Apparently it is his view that the "unpalatable choice" that a court faces in such situations becomes a gourmet exercise in democracy when imposed upon legislatures. 
Yet these are only the direct consequences of the decision. In the zero-sum world of public finance, the five hundred million dollars in new costs imposed upon the unemployment insurance (UI) program as a result of this response and Parliament's response to Tétrault-Gadoury $v$. Canada ${ }^{22}$ in which the Court ordered that Ul benefits be extended to those who are sixty-five years of age and older, impelled the government to seek further savings within the UI system. ${ }^{23}$ Such savings were achieved through additional legislative amendments increasing the number of work weeks required to qualify for UI benefits, reducing the number of weeks for which UI benefits are provided, and toughening the penalties for workers who leave their jobs without cause, refuse a suitable job, or are dismissed for misconduct. ${ }^{24}$ These amendments resulted in at least thirty thousand people losing UI benefits; with female, immigrant, elderly, and disabled workers being the hardest hit. ${ }^{25}$ These are not minor policy consequences. On the contrary, they are changes that influenced and continue to influence the lives of thousands of Canadians.

What this qualitative analysis reveals-and what quantitative analysis cannot-are the significant first- and second-order impacts that Schachter and Tétrault-Gadoury had upon public policy in Canada. Moreover, it is safe to assume that their impacts were even more farreaching than this, as governments across Canada reviewed and revised other statutory schemes in light of these rulings and incorporated them into their analysis of new legislative initiatives. ${ }^{26}$ Yet the authors

\footnotetext{
22 [1991] 2 S.C.R. 22 [ Tétrault-Gadoury].

${ }^{23}$ Joel Bakan, Just Words: Constitutional Rights and Social Wrongs (Toronto: University of Toronto Press, 1997) at 59.

${ }^{24}$ Supra note 18.

${ }^{25}$ Supra note 23.

${ }^{26}$ The federal Department of Justice, for example, "routinely reviews new legislation for potential Charter violations" by trying "to gauge the courts' likely response to legislation, based on existing case law." Matthew A. Hennigar, "Expanding the 'Dialogue' Debate: Canadian Federal Government Responses to Lower Court Charter Decisions" (2004) 37 Can. J. of Pol. Sci. 3 at 16-17. Similar reviews take place within all provincial governments. A sense of how this process influences policy-making can be gleaned from the following remarks of Jean-Pierre Blackburn, MP, during the debate on Bill C-21:

When we, as members of Parliament, want to introduce amendments, we feel there is always something hanging over our heads: namely the famous rule that our amendment may run counter to the Charter. I find this rather disturbing. It is like a form of blackmail. As soon as a member tries to move an amendment, he or she is told that it
} 
minimize the importance of such qualitative analysis. While referring to the substance of some judicial decisions and statutory sequels to illustrate their argument, they insist that all legislative responses, regardless of whether they accommodate or overcome court rulings, are evidence of dialogue. ${ }^{27}$ To the same effect, they maintain that judicial review can be characterized as "weak," even though it exerts "considerable judicial influence on the legislative process," 28 and dismiss suggestions that resulting policy distortions raise serious questions concerning the legitimacy of that influence.

While the dialogue thesis advanced by the authors relies upon quantitative rather than qualitative analysis of Charter cases to measure their impact on legislative policy, qualitative analysis of Charter cases abounds in Canadian constitutional scholarship. One of Canada's leading constitutional scholars, for example, has drawn upon his extensive qualitative analysis of Charter cases (albeit focused more on judicial decisions than on legislative responses) to reach the following conclusion concerning the impact of section 1 :

During the public debate that preceded the adoption of the Charter, there was controversy about the desirability of a limitation clause, the conventional view being that the clause "weakened" the Charter. But s.1 has probably had the effect of strengthening the guaranteed rights. [Section 1] has been interpreted as imposing stringent requirements of justification. Those requirements may be more difficult for the government to discharge than the requirements that would have been imposed by the courts in the absence of a limitation clause.

may not be in keeping with the Charter. This fear prevents us from working in the interest of all Canadians.

Minutes, supra note 20.

${ }^{27}$ It is interesting to observe in this regard that if the authors did nothing more than classify legislative responses confined to repealing laws struck down by courts, together with legislative nonresponses, as examples of "acquiescence" rather than of "dialogue," their analysis would show that legislatures acquiesced to court rulings in 34 per cent (30 of 88 ) of all the Charter cases they surveyed, and in 43 per cent ( 10 of 23 ) of the recent Charter cases they surveyed in their second article. It appears difficult to reconcile this substantial and growing rate of legislative acquiescence with the view that judicial review is a weak influence on legislative decision making in Canada. This is particularly so given that such cases do not include those such as A.G. (Que.) v. Quebec Protestant School Boards, [1984] 2 S.C.R. 66, and Baron v. Canada, [1993] 1 S.C.R. 416, in which legislatures merely implemented legislative changes recommended by the courts, nor those like Schachter, supra note 16, and Tétrault-Gadoury, supra note 22, in which legislatures were impelled by Charter rulings to undertake other major changes in legislative policy.

${ }^{28}$ Supra note 9 at 39. 
This assessment challenges a central tenet of the dialogue thesis presented by the authors, namely that section 1 of the Charter has resulted in a weaker form of judicial review. Yet nowhere do they mention this assessment, let alone answer it. This omission is extraordinary given that the constitutional scholar whose qualitative analysis led to this contrary view is none other than Peter Hogg, in a passage penned in $1992^{29}$ and repeated in the 2006 edition of his constitutional law treatise. ${ }^{30}$

So which Peter Hogg are we to believe? Is it the Peter Hogg who argued in "Charter Dialogue" and "Charter Dialogue Revisited" that section 1 weakened judicial review under the Charter? Or is it the Peter Hogg who argued in his book, Constitutional Law of Canada, that section 1 probably strengthened judicial review under the Charter? It is difficult to say. What one can say, however, is that the qualitative analysis of the cases engaged in by the latter Peter Hogg provides a stronger basis on which to make such an assessment than the predominantly quantitative analysis of the cases employed by the former Peter Hogg. ${ }^{31}$

\section{B. Lessons on Dialogue from the United States}

Even if one were to accept the flawed proposition that Charter dialogues, as defined by Hogg and Bushell, provide evidence of a weaker form of judicial review, this would not justify the conclusion that Canadian judicial review is so weak that it can escape the legitimacy debate that they acknowledge "could not be ignored" in the United States. ${ }^{32}$ To support this conclusion, one would need to examine the extent to which legislatures in the United States have been able to respond to constitutional rulings in which laws are struck down by courts. It is true that the U.S. Constitution does not contain an express limitation clause like section 1 of the Charter, but as Hogg acknowledges in the above passage from his treatise, the absence of such 1992) at 853.

${ }^{29}$ Peter W. Hogg, Constitutional Law of Canada, student ed. (Toronto: Thomson Carswell,

${ }^{30}$ Hogg, Constitutional Law, 2006, supra note 21 at 827.

${ }^{31}$ The qualitative analysis of Charter cases in Hogg's textbook would provide an even stronger basis for such an assessment if it devoted as much attention to legislative responses as it does to the judicial decisions themselves.

32 Supra note 2 at 77. 
a clause does not prevent the courts from routinely reading limitations into the constitutional rights themselves. Indeed, as Hogg also points out in his treatise, the proportionality test adopted by the Supreme Court of Canada in $R$. v. Oakes ${ }^{33}$ to give meaning to section 1 of the Charter "bears striking similarities" to the test articulated six years earlier in relation to commercial expression by the U.S. Supreme Court. ${ }^{34}$ Nor is the use of such "means-ends" tests rare in American jurisprudence. On the contrary, judicial scrutiny of means-ends relationships "may well be the most frequently invoked technique in the judicial review of the validity of federal and state legislation."35

In order to sustain the argument that Canadian judicial review is significantly weaker than its American counterpart, therefore, serious attention must be given to the existence of constitutional dialogues in the United States. Incredibly, other than a footnote in their first article referring to "conceptions of "dialogue"" in the American literature, ${ }^{36}$ the authors neglect to do this. ${ }^{37}$ This is made even more remarkable by the fact that dialogue was identified as a "central motif" in American constitutional scholarship well before the concept was introduced into the Canadian constitutional lexicon. ${ }^{38}$ The following characterization of judicial review in the United States, taken from Barry Friedman's 1993 essay, "Dialogue and Judicial Review," could just as easily have come from Hogg and Bushell's article on the Canadian Charter published four years later:

${ }^{33}[1986]$ 1 S.C.R. 103.

${ }^{34} \mathrm{Hogg}$, Constitutional Law, 2006, supra note 21 at 827, n. 4 a.

${ }^{35}$ Gerald Gunther \& Kathleen M. Sullivan, Constitutional Law, 13th ed. (Westbury, NY: The Foundation Press, 1997) at 108, n. 2.

${ }^{36}$ Supra note 2 at 79, n. 12.

${ }^{37}$ Although in a separate article written on his own in 2004, Hogg acknowledges that legislative sequels undoubtedly occur in the United States and that judicial review in that country may not be as strong as is sometimes supposed: Peter W. Hogg, "Discovering Dialogue" (2004) 23 Sup. Ct. L. Rev. (2d) 3 at 4 [Hogg, "Discovering Dialogue"].

${ }^{38}$ Stanley Ingber, "Judging Without Judgment: Constitutional Irrelevancies and the Demise of Dialogue" (1994) 46 Rutgers L. Rev. 1473 at 1479, n. 10. Examples of other recent American scholarship discussing the existence of constitutional dialogues in the United States include the following: Louis Fisher, Constitutional Dialogues: Interpretation as Political Process (Princeton: Princeton University Press, 1988); Barry Friedman, "Dialogue and Judicial Review" (1993) 91 Mich. L. Rev. 577; and Dan T. Coenen, "A Constitution of Collaboration: Protecting Fundamental Values with Second-Look Rules of Interbranch Dialogue" (2001) 42 Wm. \& Mary L. Rev. 1575. 
I call the process of judicial review that actually occurs in the workaday world dialogue. The term emphasizes that judicial review is significantly more interdependent and interactive than generally described. The Constitution is not interpreted by aloof judges imposing their will on the people. Rather, constitutional interpretation is an elaborate discussion between judges and the body politic. ${ }^{39}$

Similar views have also been voiced by members of the American judiciary, such as this excerpt from a speech delivered in 1993 by Justice Ruth Bader Ginsburg: "[J]udges play an interdependent part in our democracy. They do not alone shape legal doctrine but ... they participate in a dialogue with other organs of government, and with the people as well." ${ }^{\prime 40}$

What conclusions can be drawn from the American scholarship concerning constitutional dialogue? Above all, such scholarship provides strong support for the view, acknowledged by Hogg in his treatise, but overlooked in these articles on dialogue, that the existence or absence of an express limitation clause does not determine the extent to which judicial decisions are influential or conclusive. The U.S. Supreme Court has developed what Harry $\mathrm{H}$. Wellington has referred to as "a whole family of procedural or structural doctrines" that allow the Court to say to other governmental entities: "You may be able to achieve the substantive result you desire, but you must proceed toward your objective in a different fashion from the one you have used."

The extent and impact of such structural doctrines have been exhaustively examined in Dan Coenen's recent study, "A Constitution of Collaboration: Protecting Fundamental Values with Second-Look Rules of Interbranch Dialogue." ${ }^{42}$ Coenen documents nine structural doctrines (many with multiple sub-categories) through which the U.S. Supreme Court "initiates a" dialogue with and among non-judicial actors, often deferring to decisions of political branches on how to resolve constitutional issues, so long as those decisions bear the earmarks of deliberation and care." ${ }^{43} \mathrm{He}$ also identifies three "quasi-structural rules" and four "quasi-structural tools" that facilitate inter-branch dialogue.

\footnotetext{
${ }^{39}$ Friedman, ibid. at 653 .

${ }^{40}$ Ruth Bader Ginsburg, "Speaking in a Judicial Voice" (1992) 67 N.Y.U.L. Rev. 1185 at 1198.

${ }^{41}$ Harry H. Wellington, Interpreting the Constitution. The Supreme Court and the Process of Adjudication (New Haven: Yale University Press, 1991) at 35.

${ }^{42}$ Coenen, supra note 38.

${ }^{43}$ Ibid. at 1583.
} 
Coenen's study shows such doctrines to be so pervasive that, based on its findings, Mark Tushnet has questioned whether the United States "could get along quite well with subconstitutional doctrine and no substantive judicial review." 44

In sum, there is strong evidence in the United States, as in Canada, that constitutional decision making by the courts frequently produces "dialogues" with other branches of government. Indeed, the structural and quasi-structural devices that Coenen identifies as facilitating dialogue in the United States are more numerous than the Charter devices identified by the authors. This does not mean that constitutional dialogues occur more frequently in the United States (though there is no reason to assume that they do not, particularly if the definition of dialogue includes legislative responses acquiescing to court decisions). What it does mean, however, is that if the authors wish to make the case that Canada enjoys a weaker form of judicial review, they need to undertake a comprehensive qualitative assessment of judicial decisions and legislative responses in both countries.

Another point that emerges clearly in the American literature is the importance of distinguishing amongst opportunities for dialogue on the basis that some pose more serious obstacles than others for the attainment of governmental objectives..$^{45}$ Unlike the authors, American scholars accept that assessing the significance of dialogues requires one to attend to the nature as well as the frequency of legislative responses, the influence of the courts in shaping those responses, and the degree to which such responses involve policy compromises and deviations from legislative goals. As a result, American scholars are not prone to speaking of constitutional dialogues as answering anti-majoritarian criticisms of judicial review. Rather, they understand that, while the existence of such dialogues may influence debates over the legitimacy of judicial review, it in no way resolves them. ${ }^{46}$

44 Mark Tushnet, "Subconstitutional Constitutional Law: Supplement, Sham, or Substitute?" (2001) 42 Wm. \& Mary L. Rev. 1871 at 1880.

45 Supra note 41 at 36 . See also the debate between Professors Tushnet and Coenen as to whether judges take advantage of such obstacles to drive substantive outcomes by means of structural decisions: Tushnet, ibid; Dan T. Coenen, "Structural Review, Pseudo-Second-Look Decision Making, and the Risk of Diluting Constitutional Liberty" (2001) 42 Wm. \& Mary L. Rev. 1881.

${ }^{46}$ See generally Fisher, supra note 38. 


\section{The Significance of the Insignificance of Section 33}

One feature of the Canadian Charter that has no explicit or implicit counterpart in the U.S. Constitution is section 33, which allows legislatures to override Charter decisions by including a notwithstanding clause in statutes. The authors refer to section 33 as one of the structural features of the Charter that enables dialogue, and invoke it to support their claim that legislatures have the last word even where a legislative objective is held to be unconstitutional. However, the section does not feature prominently in their analysis. The reason they give is that the section in practice "has become relatively unimportant, because of the development of a political climate of resistance to its use." ${ }^{\prime 4}$

I agree that the political climate in Canada has rendered the use of section 33 insignificant. However, this is not true of its non-use. The relative strength or weakness of judicial review, after all, is a function of political as well as textual opportunities and constraints. Like Sherlock Holmes' famous clue of the dog that did not bark, ${ }^{48}$ the failure of legislatures to invoke section 33 speaks volumes. Given that section 33 was part of the original Charter bargain, the degree of political resistance that has built up to its use provides a powerful indicator of the dominance of legalism over democracy in the realm. of Charter decision making. ${ }^{49}$ Thus while legislatures have de jure powers to override courts under section 33, the political inability of legislatures to exercise such powers gives courts de facto final say over the constitutional acceptability of legislative objectives. Moreover, the existence of section 33 allows courts to claim that their decisions are reversible and

\footnotetext{
${ }^{47}$ Supra note 2 at 83.

${ }^{4 \mathcal{S}}$ Arthur C. Doyle, "Silver Blaze" in The Memoirs of Sherlock Holmes (Oxford: Oxford University Press, 2000) 3.

${ }^{49}$ This is due not only to the greater authority that courts command over matters that are represented as "questions of law," but also to the fact that under the Charter courts get to speak the language of "rights" while legislatures are relegated to speaking in the language of "limits"-and, in order to invoke section 33, legislatures are required to argue that rights "do not matter." See Jeremy Waldron, "Some Models of Dialogue Between Judges and Legislators" (2004) 23 Sup. Ct. L. Rev. (2d) 7 at 34-39. See also Webber, "Institutional Dialogue," in Sadurski, supra note 6 at 97, noting that constitutional rights assume "a superordinate importance, resistant to balancing," and that any effort by legislators to influence their application is seen "as an illegitimate attempt to impair fundamental liberties."
} 
therefore have democratic, as well as legal, legitimacy. ${ }^{50}$ This situation nicely illustrates the extent to which the Charter privileges judicially defined norms and places pressure on legislatures to accede to such norms even when they are legally empowered to resist them. In this way, it further calls into question the degree of influence attributed to legislatures by the authors.

Far from supporting the claim that Canada has a weaker form of judicial review, therefore, section 33 provides further grounds for doubting this proposition. Yet all of this seems lost on the authors, who are happy to point to section 33 as a device supporting dialogue when it helps to bolster their thesis, while acknowledging that it is of little practical importance when it does not.

\section{A LEGITIMATE FORM OF JUDICIAL REVIEW (OR NOT)}

The arguments marshalled by the authors to support their claim that the Charter establishes a weaker form of judicial review have not changed significantly from those presented in 1997 . The same cannot be said, however, of their arguments in favour of the Charter's legitimacy. Hogg and Bushell began their first article by expressing a high degree of skepticism about traditional justifications for judicial review:

The view that the Charter is a "bad thing" is commonly based on an objection to the legitimacy of judicial review in a democratic society. Under the Charter, judges, who are neither elected to their offices nor accountable for their actions, are vested with the power to strike down laws that have been made by the duly elected representatives of the people.

The conventional answer to this objection is that all of the institutions of our society must abide by the rule of law, and judicial review simply requires obedience by legislative bodies to the law of the constitution. However, there is something a bit hollow and unsatisfactory in that answer. The fact is that the law of the constitution is for the most part couched in broad, vague language that rarely speaks definitively to the cases that come before the courts. Accordingly, judges have a great deal of discretion in "interpreting" the law of the constitution, and the process of interpretation inevitably remakes the constitution into the likeness favoured by the judges. This problem has been captured in a famous American aphorism: "We are under a Constitution, but the Constitution is what the judges say it is."

\footnotetext{
${ }^{50}$ See e.g. Vriend, supra note 7; Beverley McLachlin, "Courts, Legislatures and Executives in the Post-Charter Era" in Paul Howe \& Peter H. Russell, eds., Judicial Power and Canadian Democracy (Montreal: McGill-Queen's University Press, 2001) 63 at 68-69.
}

${ }^{51}$ Supra note 2 at 76-77 [footnotes omitted]. 
It was against this premise of judges exercising discretion in a manner that reflects their own likenesses that Hogg and Bushell first presented their case for dialogue. They supported their claim that the Charter was "not such a bad thing after all," not by contending that there was a satisfactory justification for the powers given courts to decide Charter cases (they suggested the opposite), but rather by contending that such powers could be overcome through the capacity of legislatures to respond to judicial decisions. Indeed, they were so confident of this legislative capacity that they were emboldened to say that "the critique of the Charter based on democratic legitimacy cannot be sustained." 52

Even this overblown statement-from which they quickly retreated ${ }^{53}$ - cannot disguise the fact that Hogg and Bushell's original thesis had more to do with mitigating than legitimating the role of the courts under the Charter. It was the asserted inability of judicial decisions to undermine legislative democracy that, in their eyes, made the Charter. "not so bad." 54 In other words, judicial review is more acceptable when it is less effective, and, by implication, judicial deference is to be favoured so that courts can, as Patrick Monahan puts it, "create the space needed to permit such dialogue to occur." as no surprise, therefore, when Hogg subsequently argued that courts should accord even greater deference to legislatures that re-enact laws previously struck down by the courts. ${ }^{56}$ Based on this understanding of Hogg and Bushell's analysis, and its failure to provide a moral claim to support or guide judges' involvement in Charter decision making, I maintained that their thesis did not amount to a justification for judicial review. On the contrary, by celebrating the fact that court decisions under the Charter are ultimately less influential than is sometimes supposed, it called into question why courts should be allowed to make such decisions in the first place. ${ }^{57}$ ?

\footnotetext{
${ }^{52}$ Ibid. at 105

${ }_{53}$ Peter W. Hogg \& Allison A. Thornton, "Reply to 'Six Degrees of Dialogue”" (1999) 37 Osgoode Hall L.J. 529 at 534.

${ }^{54}$ For discussion of the implications of this view for legislative democracy, see Andrew Petter, "Look Who's Talking Now: Dialogue Theory and the Return to Democracy" in Richard W. Bauman \& Tsvi Kahana, eds., The Least Examined Branch: The Role of Legislatures in the Constitutional State (New York: Cambridge University Press, 2006) 519.

${ }^{55}$ Monahan, supra note 7 at 396.

${ }^{56} \mathrm{Hogg}$, "Discovering Dialogue," supra note 37 at 5.

${ }^{57}$ Petter, "Charter Justification," supra note 5 at 195-96.
} 
In "Charter Dialogue Revisted," the authors concede the point that "dialogue theory does not provide a justification for judicial review." 58 At the same time, they abandon the premise of the 1997 article that the subjective nature of Charter interpretation renders conventional theories of judicial review "hollow and unsatisfactory." Instead, they embrace such theories with the zeal of converts, arguing that judicial review is justified on moral, political, and legal grounds. The moral justification, they maintain, is "the idea that individuals have rights that must be 'taken seriously,' which means that they cannot be taken away simply by an appeal to the general welfare." ${ }^{160}$ In support of this tautological assertion they cite Ronald Dworkin's 1977 book, Taking Rights Seriously. ${ }^{61}$ The political and legal justifications they provide are not any more original, the former referring to the "democratic process" that gave rise to the Charter and the "popular support" it enjoys, and the latter relying on the fact that "the Charter is now part of the Constitution of Canada." ${ }^{.62}$ All of this, of course, was well known to Hogg and Bushell in 1997, and none of it comes close to answering the claim made in their original article that, regardless of the political history and legal status of the Charter, the discretion it bestows upon courts "inevitably remakes the constitution into the likeness favoured by judges." ${ }^{\prime 3}$ Moreover the reference to Dworkin is particularly ironic for two reasons. First, his is one of the "avalanche" of "ingenious theories to justify judicial review" that Hogg and Bushell identified with the United States, and which they implied was neither convincing nor required to counter anti-majoritarian objections to judicial review in Canada. ${ }^{64}$ Second, a key aspect of Dworkin's contribution to this avalanche is his assertion that there are "right answers" to constitutional questions, a claim that flat out contradicts Hogg and Bushell's prior arguments. ${ }^{65}$

${ }^{58}$ Supra note 9 at 29.

${ }^{59}$ Supra note 2 at 77.

${ }^{50}$ Supra note 9 at 28.

${ }^{6 t}$ Ronald Dworkin, Taking Rights Seriously(London: Duckworth, 1977).

${ }^{62}$ Supra note 9 at 28.

${ }^{63}$ Supra note 2 at 77.

${ }^{64} \mathrm{Ibid}$. at $77-78$.

65. It also contradicts the views of another Canadian proponent of dialogue theory, Kent Roach, who entitles an entire chapter of his book on the subject "The Myths of Right Answers," 
This shift is significant not only because it represents a renunciation of Hogg and Bushell's previous views, but also because it undermines the coherence of their thesis. That thesis, it will be recalled, was aimed at countering the anti-majoritarian objection to judicial review. The capacity of legislatures to respond to judicial decisions was deemed to be a "good thing" because it meant that the power of courts to interfere with democratic decision making was diminished. This made sense if one proceeded from Hogg and Bushell's assumption that there was no satisfactory justification for such interference. It does not make sense, however, if one takes the revised view of these authors and their new co-author, Wright, that such interference is justified on other grounds, and particularly if one takes the view that it is based on a judicial capacity to discern "right answers." In this case, the ability of legislatures to respond to judicial decisions with anything other than compliance represents a potential threat to the "legitimate" values that judicial review is designed to protect. The question of whether that capacity is a "good thing" or a "bad thing," therefore, can only be assessed with reference to those values, and the extent to which they are reinforced or undermined by legislative dialogues. Yet the authors offer no such assessment-nor could they given that, beyond asserting that the purpose of the Charter is to take rights seriously (and the suggestion that such values "often include the concerns of an aggrieved minority"66), they provide no clue as to what values (or minorities) it is designed to protect, let alone what it might mean to take them seriously.

Thus by trying to remedy one problem (their lack of a justification for judicial review), the authors have unwittingly created another even bigger problem (the abandonment of their justification for legislative dialogues). Further evidence of this can be found in their new claim that dialogue theory does not militate for or against judicial restraint ${ }^{67}$ and their insistence that Hogg's prior call for courts to show increased deference to legislation re-enacted following adverse Charter rulings "cannot be right." ${ }^{68}$ Here we see the product of a dialogue theory

with much of that chapter devoted to questioning Dworkin's claim that right answers can be derived from moral principles. See Roach, supra note 7 at 225-38.

${ }^{66}$ Supra note 9 at 45 .

${ }^{67}$ Ibid. at 47.

${ }^{68}$ Ibid. at 48. 
that has been diverted from its original mission of mitigating judicial powers that cannot be justified, and assigned new duties mitigating judicial powers that can be justified. Yet if such rights can be justified, why do judicial decisions enforcing them need to be mitigated? Is it to enable legislatures to correct judicial error? If so, some substantive theory of rights is required to ascertain when such error has occurred. Is it to guard against unintended disruption to legislation from justifiable judicial decisions? If so, the legislative role is reduced to refining the exercise of judicial power. In the reconstituted world of Charter dialogue that the authors have created, legislatures that do more than acquiesce to judicial decisions run the risk of thwarting Charter rights and subjecting themselves to further judicial censure. Moreover, given the lack of an articulated set of values to guide Charter decision making, legislatures have no basis for measuring the appropriateness of their actions other than waiting for courts to tell them what they have done wrong.

\section{CONCLUSION}

When all is said and done, the dialogue thesis advanced by the authors appears to boil down to the unremarkable insight that legislatures have the capacity to modify legislation following adverse Charter rulings by the courts. Given that such modifications include repealing provisions found to be unconstitutional by the courts and repairing other provisions in light of such repeals, it would be much more surprising if legislatures did not have this capacity. Nor is it extraordinary that legislatures are often given an opportunity to refashion legislation struck down by the courts on the basis of a meansends analysis. These and other opportunities to respond to decisions about rights are a common feature of constitutional jurisprudence in other jurisdictions, including the United States.

In addition to their banality, the above propositions do not tell us much of anything about the legitimacy of judicial review. The authors now concede that dialogue theory does not provide a justification for judicial review. Moreover, the extent to which it answers antimajoritarian objections to judicial review can be assessed only by means of qualitative analyses of the degree to which Charter decisions constrain democratic policy. In this regard, Hogg's own qualitative analysis suggests that a key feature of the Charter that he and his coauthors maintain weakens judicial review has, in fact, had the opposite 
effect. If he is right about this, dialogue theory is further undermined. Even if he is wrong, however, he and his co-authors have thrown themselves on the horns of another painful dilemma by abandoning their previous skepticism about the legitimacy of judicial review and embracing a theory which holds that rights "cannot be taken away by an appeal to the general welfare." How this theory can be reconciled with one that celebrates the capacity of legislatures to reassert majoritarian preferences through Charter dialogues-including the capacity to override Charter rights by means of section 33-is, to put it mildly, a mystery.

By shifting ground in this way, the authors have transformed a thesis that was coherent but unconvincing into one that is simply incoherent. Yet no one should think for this reason that dialogue theory is about to loosen its hold on the constitutional imagination of Canadian courts. As suggested by the subtitle of their article in this issue, ${ }^{69}$ dialogue theory's appeal derives more from its power as a metaphor than its force as an argument. By portraying judicial review as a contribution to deliberative engagement, the dialogue metaphor recasts judges as advocates within a democratic process rather than as arbiters within an authoritarian regime. Similarly, by representing judicial decisions under the Charter as transitory and reversible by legislatures, the dialogue metaphor purports to relieve judges of responsibility for the consequences of their Charter rulings without constraining their Charter powers.

Given the ongoing pressure felt by courts to defend a form of judicial review that was imposed upon them, and in the absence of a more compelling justification for Charter decision making, it is hardly surprising that judges would embrace a metaphor that offers them all of this, and comes with a seal of academic approval. For these reasons, dialogue theory will likely continue to thrive as a metaphor, notwithstanding its deficiencies as an argument. Metaphors, it seems, have something in common with idols. Where the need is great. and there is a constituency that wants to believe, their capacity to engender reverence is not impaired by their likelihood of being false.

${ }^{69}$ Supra note 9. 
